\author{
Samofatova V. \\ Doctor of Economics, Associate Professor \\ Department of Industrial Economics \\ Odessa National Academy of Food Technologies \\ Kanatna str., 112, Odesa, Ukraine, 65039 \\ E-mail: vica_samofatova@meta.ua \\ ORCID ID: 0000-0002-9058-4382
}

\title{
STRATEGIC DIRECTIONS OF SUSTAINABLE AND INCLUSIVE DEVELOPMENT OF THE AGRI-FOOD SPHERE
}

It has been noted that despite the important role of the agri-food sphere both in the domestic and in the world market, it requires systemic transformations on the basis of sustainability and inclusiveness. The essence of the concepts of "sustainable development", "inclusive development" of the agri-food sphere from the standpoint of the systemic approach has been considered. The main strategic directions of sustainable and inclusive development of the agri-food sphere has been determined in accordance with the strategy "Europe 2020": formation and development of clusters, smart specialization, innovative development, digitalization. It has been noted, that the achievement of sustainable inclusive development of the agri-food sphere is one of the key tasks. The features and role of intelligent specialization and clusters in providing sustainable inclusive development have been determined. The strategic vision of sustainable and inclusive development of the agri-food sphere has been proposed.

Keywords: sustainable development, inclusive development, cluster, agri-food sphere (AFS), strategic directions.

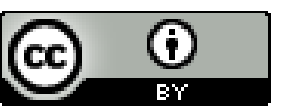

This work is licensed under a Creative Commons Attribution 4.0 International License http://creativecommons.org/licenses/by/4.0/
Statement of the problem and its connection with important scientific and practical tasks Over the past decades, the agri-food sphere (AFS) has achieved a steady positive dynamics and is increasingly goining the production of both agricultural and food industries. According to the Ministry of Agrarian Policy and Food, in the year 2018 Ukrainian agricultural exports grew by more than $\$ 880$ million compared with 2017 and reached a new record of $\$ 18.5$ billion. At the same time, Ukraine exported products to the EU countries as many as 5.8 billion dollars, thus forming a rather serious positive balance in our bilateral trade [1].

At the same time, positive changes in the agrifood sphere have not yet provided the proper improvement of the living conditions of the population of rural areas and small agricultural cities. Therefore, its further functioning has been requiring, first of all, qualitative transformations capable of ensuring sustainable inclusive development and food security of the state. In particular, the important problems of the agri-food sphere are the need to create a significant gross value added in the final production of products, the growth of export opportunities and employment of the population.

Ukraine's choice of the European vector of development requires study and implementation of program documents, in particular, "Strategy 2020", which includes a smart, sustainable and inclusive economy.

Therefore, the relevance of the problem under investigation is indisputable and is related to the need to ensure the sustainable and efficient functioning of the economy of the agri-food sphere, the provision of ade- quate revenues in villages and small agrarian towns, the approximation of parameters of the quality of life in rural areas to urban characteristics and its integration into the global economic system.

The analysis of the latest publications on the problems. The economic essence of the concept of "inclusiveness" is comprehensively considered and analyzed in the works of the well-known economists J. Robinson and D. Eisemoglu, where it is stated that Eng. "Inclusive" characterizes the involvement (inclusion) in the process of all, without distinctions and restrictions [2]. The problem of inclusive development was also studied by J. Gupta [3], T. Zinchuk [4], L. Fedulova [5]. The concept of sustainable development is the quintessence of the world of scientific thoughts thanks to the works of the Roman Club, Danielle and Dennis Meadows [6] and the works of many other researchers.

Spatial aspects of the transformation of the agrifood sphere in the context of social problems have been investigated in the works of M. Baranovsky [7]. Cluster development and the principles of strategic management of the sustainable development of the agri-food sphere of the region have been considered in the works of the author [8], [9].

Forming of the aims of the research. The purpose of the article is to outline the strategic directions of sustainable and inclusive development of the agri-food sphere and the peculiarities of their achievement.

Giving an account of the main results and their substantiation. Ensuring sustainable development of the agri-food sphere is one of the conditions for ensur 
ing the national security of Ukraine and welfare of the people. The characteristics of the concept of sustainable development in the agri-food sphere were formulated in the materials, adopted at the session of FAO (Food and Agriculture Organization of the United Nations) in Rome in 1996, as follows: "The main task of the program is the development of the agri-food sphere and the agriculture of Ukraine to produce food and provide food security. To address this challenge, educational initiatives should be supported as well as using economic innovation and the development of innovative technologies, thus providing more access to foods products that people need in nutrition; access to them for all population groups; development of commodity production; the reduction of unemployment and raise of the level of income from the simultaneous struggle against poverty; management of the use of natural resources and environmental protection"[10].

The agri-food sphere performs primarily economic, ecological and social functions. It meets the needs of the population in food and provides food and other processing industries with raw materials. AFS provides reproduction and development of labor potential, supports environmental activities and preserves the cultural traditions of our people. In our opinion, the agri-food sphere has a complex structure and consists of natural resource potential, agri-industrial complex and a combined rural-urban continuum. The term "agri-food sphere" correlates with the biological term "biosphere" and is an important component connected with support of the society. The AFS's economic function is to achieve sustainable development and market competitiveness. The social function is ensuring rational employment and the corresponding level of income in rural areas and small agrarian towns. The ecological function is to preserve and improve the natural resource potential (air, water resources, soils, agri-landscapes, etc.).

The concept of sustainable and inclusive development is complementary and effects all its constituents and executable functions. Sustainable development forms the foundation for inclusive development. In particular, in the generalized sense, inclusive (from English inclusiveness - engagement) is a modern interpretation of contemporary development, the essence of which is to increase the involvement of all segments of society and the different statuses of groups, as well as the inclusion of all territories in this process.
With regard to the agri-food sphere, this means that its development should be ensured by increasing the efficiency and integrated use of all types of resources, based on the introduction of innovation, integration, intelligent specialization and attracting the rural population and small agrarian cities to productive activities.

According to $\mathrm{T}$. Zinchuk, it is necessary to ensure sustainable development of the agri-food series, which would contribute to the formation and implementation of the innovative human-centric model of its economy [4, p. 133].

I. Irtyshcheva believes that "the development of agricultural production depends on the attitude of society to social problems, especially the rural population, the level of its qualifications and culture, the motivation of its labor and social activity in introducing innovations in production and sustainable development" [11, c. 75].

Familiazation with the research results of contemporary foreign scientists makes it possible to distinguish the main general scientific principles that form the basis of inclusive development, in particular, such as: participation in management, distribution of profits; absence of discrimination; accessibility to growth benefits; providing equal opportunities for obtaining benefits, etc. [12].

J. Gupta and other researchers have noted that the ideas of "inclusive development" appeared in the second half of the 20th century, focusing on different levels, including personality, state and international relations. At the same time, in the Academic literature, the first publications appeared in 1998, and have been actively used since 2008. Until then, the economic Paradigm of development has traditionally dominated the economic perspective in which industrialization and productivity were seen as the main factors of development [3, p. 35].

Under the current conditions, structural transformation of the agri-food sphere should be ensured, using the principles of inclusiveness, sustainability, and reasonable specialization. In this regard, study and generalization of the imperatives of the European Union's development, namely, "Strategy 2020", to form priority areas for the functioning of the agri-food sphere, deserve attention, "Strategy 2020" aims to ensure smart, sustainable and inclusive development (Table 1).

Table 1

Strategic components of sustainable and inclusive development of the agri-food sphere according to the "Europe 2020" strategy*

\begin{tabular}{|c|c|c|}
\hline $\begin{array}{c}\text { Strategic } \\
\text { components }\end{array}$ & Essence & Areas of investment activity in AFS \\
\hline $\begin{array}{c}\text { Smart } \\
\text { development }\end{array}$ & $\begin{array}{l}\text { - activating of innovative development; } \\
\text { - increase of digitalization; } \\
\text { - providing the population with food } \\
\text { products of its own production }\end{array}$ & $\begin{array}{l}\text { - formation and development of agri-food } \\
\text { innovative clusters; } \\
\text { - development of rural Green tourism; } \\
\text { - development of a reasonable specialization, } \\
\text { digitalization. }\end{array}$ \\
\hline $\begin{array}{l}\text { Sustainable } \\
\text { development }\end{array}$ & $\begin{array}{l}\text { - transition to a low carbon economy; } \\
\text { - preservation and protection of the envi- } \\
\text { ronment and increase of resource efficiency; } \\
\text { - promoting sustainable infrastructure devel- } \\
\text { opment. }\end{array}$ & $\begin{array}{l}\text { - reduction of energy intensity of production; } \\
\text { - development of bioenergy and biotechnology; } \\
\text { - innovations in sustainable use of nature; } \\
\text { - complex processing of raw materials. }\end{array}$ \\
\hline $\begin{array}{c}\text { Inclusive } \\
\text { development }\end{array}$ & $\begin{array}{l}\text { - promotion of stable and high-quality } \\
\text { employment; } \\
\text { - -investment in education and training; } \\
\text { - effective public administration. }\end{array}$ & $\begin{array}{l}\text { - development of cluster-network model of } \\
\text { production; } \\
\text { - growth of skills and support of young people } \\
\text { desire for development; } \\
\text { - implementation of the potential of employees in } \\
\text { related activities. }\end{array}$ \\
\hline
\end{tabular}

*developed by the author for [13] 
All types of development are interconnected and long-term. Important attention should be paid to productive employment in the agri-food sphere as a way to implementing an inclusive approach. Among the most important aspects of inclusive development is the structural transformation of the agri-food sphere, the creation of new jobs, investment in human potential. In addition, alternatives to sustainable development of the agri-food sphere on the innovative basis do not exist, as it is possible to compete in the world markets only using the latest production technologies and organizational and managerial innovations.

One of the most effective ways to achieve these parameters in the agri-food sphere is the introduction of a cluster-network model of development, which was considered in more detail by the author in papers $[9,10]$. In the world practice, the cluster model of production has become widespread, as it ensures the creation of a competitive, innovative and investment-attracting economy, the ultimately results of which is to rise the level and quality of life of the population. Important incentives for the formation of agri-food clusters are the following factors: convenient economic-geographical location, favorable natural and climatic conditions, successful operations of processing enterprises, availability of personnel, specialized institutions of higher education (IHE) and research institutes (research institutes), developed infrastructure and others.

Creation of clusters is particularly relevant when the reform of the agri-food sector is increasingly affecting the level of territorial communities, whose economic independence is increasing at this stage of development, generating new, more complex tasks, which require new ways of solving. The so-called "agrarian towns" located on the territory of the region in the immediate vicinity of a certain agri-food production should become the center for cluster formation in the agri-food sphere of the region.

The methods of strategic management steps are presented on the strategic vision of sustainable and inclusive development of the agri-food sphere (Fig. 1).

\section{The strategy of sustainable and inclusive development of the agri-food sphere}

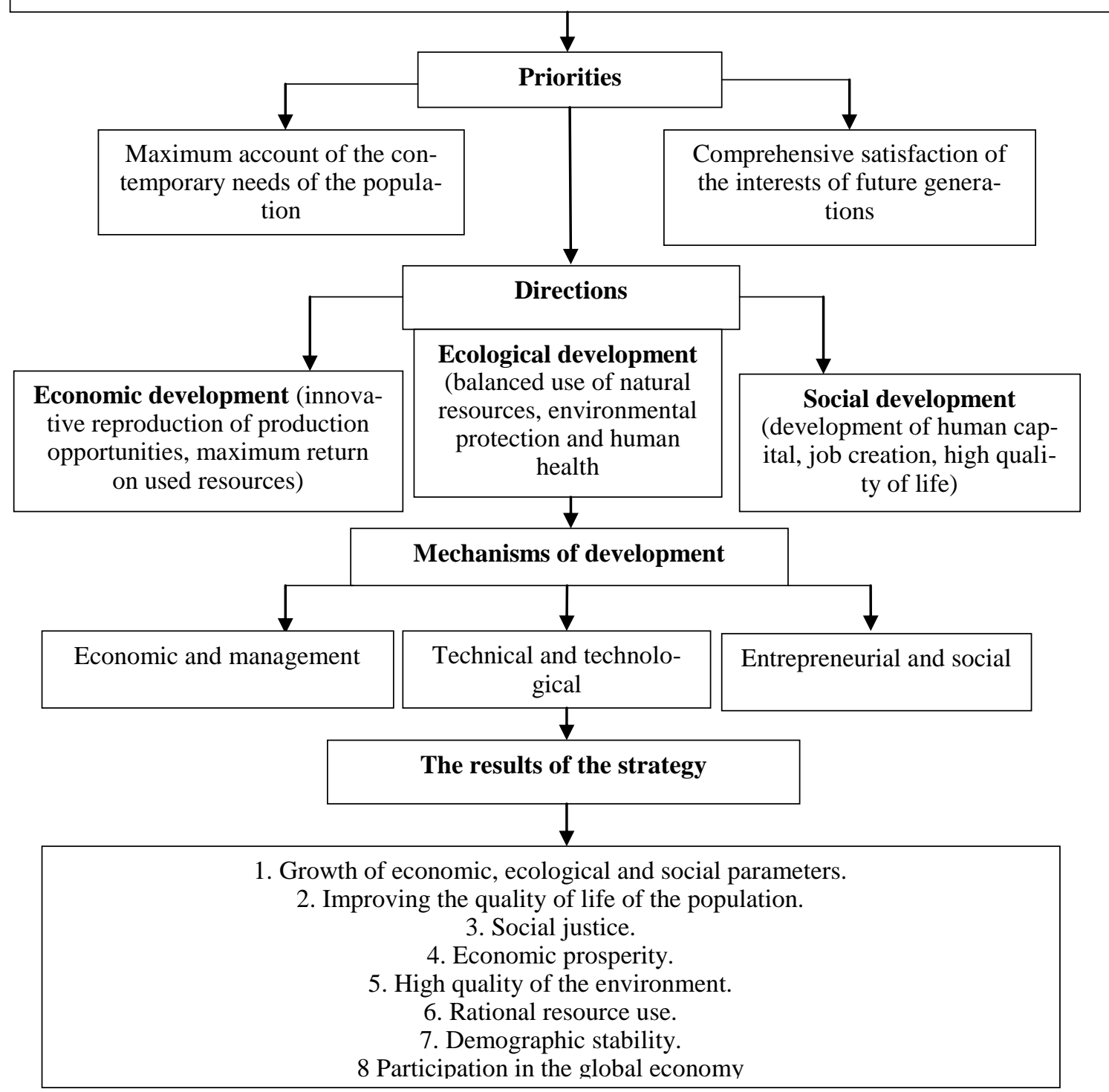

Fig. 1. Strategic structure of sustainable and inclusive development of the agri-food sphere* *improved by the authors for [Niemets, p.36] 
Mechanism for achieving sustainable and inclusive development of the agri-food sphere has: technical and technological, as well as economic-managerial and entrepreneurial-social directions. Once the strategy has been implemented, it is necessary to monitor and evaluate the implementation of the strategy in certain periods.

This strategy focuses, first of all, on the efficient use of human potential in the agri-food sphere and aims at ensuring a high quality of life for present and future generations.

Conclusions and prospects for further investigations. Consequently, the concept of sustainable and inclusive development of the agri-food sphere, broadens the range of its economic growth, focusing on the need to ensure the appropriate level and quality of life of people in rural areas and small agrarian towns. A key aspect of the sustainable and inclusive development of the agri- food sphere is to promote innovation and the full engagement of workers and business entities. It is advisable to do this through the development of a cluster-net economy, which should be promoted by state agricultural policy. The strategic components of the development of the agri-food sphere have been formed and a strategy for sustainable and inclusive development has been developed that will provide synergistic growth, economic, environmental and social characteristics that will lead to demographic stabilization and participation in the global economy with high added value products.

The prospects for further development are related to the improvement of the mechanisms of innovation development and the interaction of science, business and the state in agri-food clusters. Important will be the study and use of advanced European experience and participation in international cooperation programs.

\section{References}

1. Ukrainskyi ahrarnyi eksport zris do krain YeS. Ministerstvo ahrarnoi polityky ta prodovolstva Ukrainy. (2018, February 05). Retrieved January 25, 2019, from http://minagro.gov.ua/node/25274

2. Acemoglu, D., \& Robinson, J. A. (2012). Why nations fail: The origins of power, prosperity, and poverty. New York: Crown Publishing Group.

3. Gupta, J., Cornelissen, V., \& Ros-Tonen, M. (2015). Inclusive development. In P. H. Pattberg \& F. Zelli (Eds.), Encyclopedia of Global Environmental Governance and Politics. Cheltenham, UK /Northampton, MA, USA: Edward Elgar Publishing Limited.

4. Zinchuk, T. O. (2016). Na pochatku poshuku stratehii inkliuzyvnoho zrostannia svitovoi ekonomiky: Svitovyi ta yevropeiskyi pidkhid. Visnyk Sumskoho Natsionalnoho Ahrarnoho Universytetu, (4 (68)), ekonomika i menedzhment, 132-137.

5. Fedulova, L. I. (2016). Inkliuzyvni innovatsii v systemi sotsialno-ekonomichnoho rozvytku. Ekonomika: Realii Chasu, (3 (25)), 56-65. Retrieved January 25, 2019, from http://economics.opu.ua/files/archive/2016/n3.html

6. Medows, D., Randers, J., \& Medows, D. (2004). Limits to Growth: The 30-Year Update (pp. 1-382, Rep.). Chelsea Green Publishing.

7. Baranovskyi, M. Post-Soviet Transformation of Rural Space of Ukraine. Human Geography Journal, (23 (2)), 23-29.

8. Samofatova, V. (2018). Cluster development of the agri-food sphere of the Southern region: The foreign economic activity aspect. Food Industry Economics, 10(1), 3-8. doi:10.15673/fie.v10i1.859

9. Samofatova, V. A. (2017). Principles of strategic management of sustainable development of agri-food sphere of the region. Agricultural and Resource Economics: International Scientific E-Journal, 3(1), 173-181. Retrieved January 25, 2019, from www.are-journal.com.

10. Food and Agriculture Organization of the United Nations. Retrieved January 25, 2019, from http://www.fao.org

11. Irtyshcheva, I. O. (2009). Rehionalnyi innovatsiinyi rozvytok ahroprodovolchoi sfery: Suchasnyi stan ta zavdannia upravlinnia. Rehionalna Ekonomika, (4), 71-79.

12. Klasen, S. (2010). Measuring and Monitoring Inclusive Growth: Multiple Definitions, Open Questions, and Some Constructive Proposals (Vol. 12, pp. 1-23, Working paper). ADB.

13. Europe 2020. European Commission. Retrieved January 25, 2019, from http://ec.europa.eu/europe2020/index_en.htm

14. Niemets, L., Lohvynova, M., Kandyba, Yu., Klyuchko, L., \& Kraynukov, O. (2018). Transformation of the agrarian sphere of Ukraine: Approaches to study. Human Geography Journal, 24, 31-38.

Received 28 January 2019

Approved 11 February 2019 Available in Internet 19.03.2019 


\author{
Самофратова B.A. \\ доктор экономических наук, доцент \\ кафедра экономики промышленности \\ Одесская национальная академия пищевых технологий \\ ул. Канатная, 112, г. Одесса, Украина, 65039 \\ E-mail: vica_samofatova@meta.ua \\ ORCID ID: 0000-0002-9058-4382
}

\title{
СТРАТЕГИЧЕСКИЕ НАПРАВЛЕНИЯ УСТОЙЧИВОГО И ИНКЛЮЗИВНОГО РАЗВИТИЯ АГРОПРОДОВОЛЬСТВЕННОЙ СФЕРЫ
}

В статье отмечено, что несмотря на успехи агропродовольственной сферы на внутреннем и мировом рынке, она нуждается в системных трансформациях на основе устойчивости и инклюзивности. Акцентировано внимание на том, что выбор Украиной Европейского вектора развития, требует изучения и имплементации программных документов, в частности «Стратегии-2020», включая умную, устойчивую и инклюзивную экономику.

Рассмотрена сущность понятий «устойчивое развитие» и «инклюзивное развитие» агропродовольственной сферы с позиций системного подхода. Проанализированы предпосылки инклюзивного развития, в частности, такие как: совместное участие в управлении распределении прибыли; отсутствие дискриминации; доступность к выгодам экономического роста; предоставление равных возможностей получения благ.

Определены основные стратегические направления устойчивого инклюзивного развития агропродовольственной сферы в соответствии со стратегией «Европа-2020»: формирование и развитие кластеров, умная специализация, инновационное развитие, цифровизация. Отмечено, что важное внимание должно уделяться производительной занятости в агропродовольственной сфере как способу реализации инклюзивного подхода. Акцентировано внимание на том, что наиболее важными аспектами инклюзивного развития являются: структурная трансформация агропродовольственной сферы, создание новых рабочих мест, инвестиции в человеческий потенциал

Определены особенности и роль разумной специализации и кластеров для обеспечения устойчивого инклюзивного развития. Предложена стратегия устойчивого и инклюзивного развития агропродовольственной сфреры, которая включает приоритеты, направления достижения и механизмы достижения.

Ключевые слова: устойчивое развитие, инклюзивное развитие, кластер, агропродовольственная сфера (АПС), стратегические направления.

\section{Самофратова B.A.}

доктор економічних наук, доцент кафедра економіки промисловості

Одеська національна академія харчових технологій

вул. Канатна, 112, м. Одеса, Україна, 65039

E-mail: vica samofatova@ meta.ua

ORCID ID: 0000-0002-9058-4382

\section{СТРАТЕГІЧНІ НАПРЯМИ СТАЛОГО ТА ІНКЛЮЗИВНОГО РОЗВИТКУ АГРОПРОДОВОЛЬЧОї СФЕРИ}

У статті зазначено, що незважаючи на успіхи агропродовольчої сфери на внутрішньому і світовому ринку, вона потребує системних трансформаціях на основі стійкості та відкритості. Акцентовано увагу на тому, що вибір України Європейського вектора розвитку, вимагає вивчення та імплементації програмних документів, зокрема «Стратегії-2020», включаючи розумну, сталу і інклюзивну економіку.

Розглянуто сутність понять «сталий розвиток» і «інклюзивний розвиток» агропродовольчої сфери з позицій системного підходу. Проаналізовано передумови інклюзивного розвитку, зокрема, такі як: спільна участь в управлінні розподілі прибутку; відсутність дискримінації; доступність до вигод економічного зростання; надання рівних можливостей отримання благ.

Визначено основні стратегічні напрямки сталого інклюзивного розвитку агропродовольчої сфери у відповідності зі стратегією «Європа-2020»: фрормування та розвиток кластерів, розумна спеціалізація, інноваційний розвиток, цифровизация. Відзначено, що важливе увага повинна приділятися продуктивній зайнятості в агропродовольчій сфері як способу реалізації інклюзивного 
підходу. Акцентовано увагу на тому, що найбільш важливими аспектами інклюзивного розвитку є: структурна трансформація агропродовольчої сфери, створення нових робочих місць, інвестиції в людський потенціал

Визначено особливості та роль розумної спеціалізації і кластерів для забезпечення сталого інклюзивного розвитку. Запропоновано стратегію сталого та інклюзивного розвитку агропродовольчої сорери, яка включає пріоритети, напрямки досягнення і механізми досягнення.

Ключові слова: сталий розвиток, інклюзивний розвиток, кластер, агропродовольча сфера (АПС), стратегічні напрямки.

\section{Література}

1. Український аграрний експорт зріс до країн СС. Міністерство аграрної політики та продовольства України: веб-сайт. URL: http://minagro.gov.ua/node/25274 (дата звернення: 25.01.2018).

2. Acemoglu, Daron, James A. Robinson. Why nations fail: the origins of power, prosperity, and poverty. New York, Crown Publishing Group, 2012. 544 p.

3. Gupta J., Cornelissen V., Ros-Tonen M. Inclusive development // Encyclopedia of Global Environmental Governance and Politics, Publisher: Edward Elgar Publishing Limited: Cheltenham, UK /Northampton, MA, USA, Editors: Pattberg P.H., Zelli F., 2015, pp. 35-44.

4. Зінчук Т. О. На початку пошуку стратегії інклюзивного зростання світової економіки: світовий та європейський підхід // Вісник Сумського національного аграрного університету. Серія: Економіка і менеджмент. Суми, 2016. Вип. 4(68). С. 132-137.

5. Федулова Л. І. Інклюзивні інновації в системі соціально-економічного розвитку // Економіка: реалії часу: науковий журнал / ОНПУ, Одеса, 2016, № 3 (25). C. 56-65. URL: http://economics.opu.ua/files/archive/2016/n3.html (дата звернення: 25.01.2019)

6. Medows, D., Randers, J., Medows, D. (2004). Limits to Growth: The 30-Year Update. White River Junction, VT: Chelsea Green Publishing, 2004, 382 p.

7. Mykola Baranovskyi. Post-Soviet Transformation of Rural Space of Ukraine // Human Geography Journal / V. N. Karazin Kharkiv National University. Kharkiv. Vol. 23(2). pp. 23-29.

8. Samofatova V. Cluster development of the agri-food sphere of the Southern region: the foreign economic activity aspect // Food industry economics, 2018. Vol. 10, issue1. pp. 3-8. DOI: 10.15673/fie.v10i1.859

9. Samofatova V. A. Principles of strategic management of sustainable development of agri-food sphere of the region // Agricultural and Resource Economics: International Scientific E-Journal. Kharkiv, 2017, vol. 3, no. 1, pp. 173-181, URL: www.are-journal.com (дата звернення: 25.01.2018 р.)

10. Food and Agriculture Organization of the United Nations: веб-сайт. URL: http://www.fao.org (дата звернення: 25.01.2018 р.)

11. Іртищева I. О. Регіональний інноваційний розвиток агропродовольчої сфери: сучасний стан та завдання управління // Регіональна економіка: наук. журн. / Інститут регіональних досліджень. Львів, 2009 . № 4. C. 71-79.

12. Klasen S. Measuring and Monitoring Inclusive Growth: Multiple Definitions, Open Questions, and Some Constructive Proposals // ADB Sustainable Development Working Paper Series, ADB, 2010, vol. 12. p. 23.

13. Europe 2020. European Commission: веб-сайт.URL: http://ec.europa.eu/europe2020/index_en.htm (дата звернення: 25.01.2018 р.)

14. Lyudmyla Niemets, Maryna Lohvynova, Yuriy Kandyba, Lyudmyla Klyuchko, Oleksiy Kraynukov. Transformation of the agrarian sphere of Ukraine: approaches to study // Human Geography Journal / V. N. Karazin Kharkiv National University Kharkiv, 2018. Vol. 24, pp. 31-38.

Стаття надійшла 28.01.2019 Стаття прийнята до друку 11.02.2019 Доступно в мережі Internet 19.03.2019

Цитування згідно ДСТУ 8302:2015

Samofatova V. A. Strategic directions of sustainable and inclusive development of the agri-food sphere // Food Industry Economics. 2019. Vol.11, Issue 1. P. 10-15; doi:10.15673/fie.v11i1.1290

Cite as APA style citation

Samofatova V. A. (2019). Strategic directions of sustainable and inclusive development of the agri-food sphere. Food Industry Economics, 11(1), 10-15; doi:10.15673/fie.v11i1.1290 